\title{
VIEWPOINTS
}

\section{Bribery and Corruption from a Shariah Perspective}

\author{
Mohammad Hashim Kamali ${ }^{*}$
}

The on-going campaign Malaysia is waging against corruption has gained momentum. Tunku Abdul Aziz called it an "All-Malaysian duty" in which everyone should take part regardless of political affiliation (NST, 5 January, 2013). I would also add that it is an all-Muslim duty and an appeal to the religious conscience of the Muslims of this country. Playing a proactive role in this campaign is a veritable 'amal șalih, the right moral action that the Qur'an repeatedly enjoins upon all Muslims. It is also an act with great societal benefit that elevates the standing of the ummah and Malaysia in the international community. Fighting bribery (rashwah) and corruption (fasād) is an integral part of the teachings of the Qur'an and hadith. The Qur'an prohibits "devouring/ misappropriation of the property of others" (akl al-māl bi'l-bătil, Q 4:29 and $2: 188$ ), which is a broad concept that subsumes such other offences as fraud, hoarding, theft, and gambling. The text also condemns those in authority who spread corruption and mischief among people, bestowing favours on some and oppressing others (Q 28:4 and 89:10-12). The Prophet Muhammad, pbuh, added his voice to say that all the parties to bribery, "the bribe-taker, the bribe-giver, and their go-between," provoke Allah's wrath and condemnation. It is further reported that the "Messenger of Allah cursed the donor of rashwah and its recipient in all matters that involve a judgement or ruling." The renowned Companion Abdullah ibn Masud went on record to say: "When a man removes hardship form another and then receives a gift from him, large or small, he has taken something which is harām for him."

The scope of rashwah is extended to financial transactions between members of the public and government officials which are manifestly favourable to the latter. In this way sale, lease, hire, and partnership that are so concluded fall under bribery. The second caliph 'Umar b. al-Khattab (d. 644 CE) expropriated the properties some of his officials had accumulated due to favours they had received. The caliph divided the assets in question and surrendered a portion thereof to the public treasury. This was done in the case of prominent figures, 
including Abu Hurayrah, 'Amr ibn al-'Aas, Nafi' ibn 'Amr, Saad ibn Abi Waqas, Khalid ibn al-Walid, and the governors respectively of Bahrain, Egypt, Makkah, Kufah and Shām. The practice was later institutionalised under the Abbasid caliph, Jaafar al-Mansure, when a department known as Diwan al-Musadirin was established for handling expropriation matters involving government officials, merchants, contractors and anyone who worked or conducted business with the government and accumulated disproportionate amounts of wealth. An interesting incident involved the two sons of the caliph 'Umar al-Khattab, 'Abdullah and 'Ubaydullah, who accompanied an army contingent from Madinah to Iraq. In his eagerness to please his guests, the governor of Basrah, Abu Musa al-Ashaari, told them: "Here is some money which I was about to send to the Caliph. Maybe I can advance it to you to buy some goods in Iraq and sell them in Madinah. Give the capital to the treasury and keep the profit." They did so, but when the Caliph learned of it, he asked: "Does he [al-Ashaari] give similar advances to everyone in the army?" His sons were present and were ordered to pay both the capital and the profit to the treasury.

The pious caliph 'Umar b. Abd al-Aziz (d.724 CE) went on record to say: "I am of the view that the ruler should not indulge in trading. It is not lawful for an officer also to trade in the area of his office because when he engages in trade, he may misuse his office in his own interest even if he does not intend to do so."

Fasād is more general than rashwah as it encompasses dishonesty, betrayal of trust, abuse of power, and deceit in both private and public dealings. Rashwah refers to private gain from public office or seeking recompense for rendering duties ordinarily considered as non-compensatory.

Because of the numerous forms it can take, corruption escapes comprehensive definition. It knows no boundaries, applies to rich and poor, to individuals and communities, and tends to have a cultural dimension. Whereas conduct such as officials demanding bribes is considered corrupt in virtually all societies, attitudes vary as to gift giving and cronyism among countries and cultures.

It is forbidden for government officials to accept any kind of bribe from anyone, whether gift, donation or contribution, in the course of duty. This holds regardless of whether the gift is specified or unspecified and benefits the official directly or in some other way. Other forms of enrichment that materialise through misuse of public assets may amount to a breach of trust (khiyannah) and embezzlement (ikhtilās), which are also prohibited.

A gift that has not yet been received by the official should be returned to the donor, but if this cannot be done, it should be paid to the public treasury. If an official takes bribes or unjustly appropriates the property of another, the ruler is obliged to return the assets to its true owner and to punish the offender accordingly. 
All bribery is presumed to distort justice and violate public interest. In a section of their book, The Islamic Attack on Corruption, Zafar Iqbal and Mervyn Lewis wrote: "On the moral plane, there is zero tolerance for bribery in Islam, and Islam rejects the idea that bribery serves as "the grease that oils the economic wheels."” Further, there is no scope whatsoever for legalising corruption in various guises of commission, gift, donation, advances and soft loans. The touchstone of differentiation revolves around the question whether these payments and favours would accrue had the suspect been at home without official position or profile.

\section{Note}

* Mohammad Hashim Kamali, Founding Chairman and CEO of IAIS Malaysia, graduated from Kabul University, and took his PhD in Islamic and Middle Eastern Law at the University of London in 1969. Professor Dr M.H. Kamali served as Professor of Islamic Law and Jurisprudence at the International Islamic University Malaysia (IIUM, 1985-2007), then Dean of the International Institute of Islamic Thought and Civilization (ISTAC). He also held Visiting Professorships at McGill University's Institute of Islamic Studies; Capital University, Ohio; and the Wissenschaftskolleg, Berlin. A member of the Constitution Review Commission of Afghanistan (2003), he has provided expert legal consultation to the new constitutions of Iraq, the Maldives and Somalia. Eminent authority on Islamic legal studies, he has published over 150 academic articles and 35 texts, including standard textbooks at universities worldwide. 